\title{
Uma nova ponte editorial na língua portuguesa
}

\section{A new editorial bridge in the Portuguese language}

\author{
Eduardo Leite ${ }^{1}$ \\ 1 Diretor RE3; \\ Editor Chefe Revista Académica \\ E-mail: eduardoleite@gmail.com
}

A publicação do V1N3 da RE3 assinala uma mudança de titularidade e gestão do periódico para uma nova entidade, a Ponte Editora. Trata-se de uma editora académica classificada de startup, incubada na Startup Madeira, tendo como visão:

Formar uma pátria de língua portuguesa tendo por base a ciência. Beneficiar da dinâmica da globalização para cruzar fronteiras e mares, estabelecendo a ponte entre culturas, povos e cidadãos de múltiplas comunidades espalhadas pelo mundo. Responder aos desafios da sociedade contemporânea.

Assim, no âmbito das ciências sociais, conjuntamente com outros periódicos oportunamente fundados em diferentes áreas do saber, a RE3 integra a desafiante missão da Ponte Editora:

Produção e difusão de investigação técnica e científica em língua portuguesa, de forma a contribuir, a longo prazo, para o crescimento internacional e reconhecimento do português enquanto língua científica.

No cumprimento desta missão, deparamo-nos com dificuldades significativas, resultantes dos factores seguintes: i) hegemonia da língua inglesa, enquanto língua científica; ii) falta de reconhecimento e prestígio internacional dos periódicos em língua portuguesa; iii) número reduzido de periódicos indexados a bases de dados internacionais, designadamente a ISI e a Scopus; iv) falta de apoio institucional, por parte das entidades científicas nacionais, às publicações em português; v) reduzido impacto internacional da ciência produzida em português.

Neste cenário, dominado pela língua inglesa e pelas instituições anglo-saxónicas, é extremamente difícil, tanto para as universidades de língua portuguesa, como para os investigadores, por si só, destacarem-se no panorama científico internacional. É no quadro destas adversidades que emerge a necessidade de cooperação pessoal e institucional, tanto internamente, como ao nível transnacional.

Este problema é transversal a todos os países da CPLP. Com efeito, só a cooperação entre investigadores, instituições e respetivos países pode colmatar algumas das nossas deficiências, como por exemplo: a falta de interesse da comunidade científica no que é 
publicado em português; a dificuldade em competir, especialmente na Europa, com as instituições britânicas e, no mundo, com as instituições norte-americanas. Por outro lado, a cooperação pode potenciar os nossos pontos fortes, tais como o facto de sermos 260.000 .000 de falantes da língua portuguesa, o que nos coloca entre as línguas mais faladas do mundo; a cobertura geográfica global, através da presença nos cinco continentes, por via da CPLP e/ou Diáspora; mercado de trabalho significativo e diversificado, desde os negócios, designadamente o petróleo e o gás natural, passando pelo ambiente e ecologia, culminando no turismo e serviços; a vantagem competitiva que advém do conhecimento particular destes mercados.

É nesta linha que temos vindo a trabalhar na RE3. Implementando, por exemplo, uma rede de investigadores e editores na CPLP, com objetivos comuns. Atualmente, somos mais de 50 investigadores, sendo dois terços doutores e os restantes mestres e especialistas. Recebemos contributos de Angola, Brasil, Portugal, Timor Leste, entre outros países.

Um bom exemplo dos resultados desta cooperação vem de Timor Leste e é dado por Sua Excelência, o Senhor Ministro de Estado e da Presidência do Conselho de Ministros do VI Governo Constitucional, Dr. Agio Pereira. Não obstante a sua intensa atividade política, não descura a investigação, aceitando de imediato o nosso desafio de versar sobre as questões relacionadas com a CPLP e a língua portuguesa, no quadro da globalização à qual estamos todos ligados, desde as históricas explorações marítimas que nos uniram e jamais separaram. Aproveitou, ainda, para fazer um convite ao investimento em Timor Leste, apresentando um quadro altamente favorável às empresas e empreendedores de língua portuguesa.

Por tudo isto, resta-me agradecer aos colegas e parceiros a realização da RE3. Pretendemos, ainda em 2017, continuar o trabalho, agora enquanto startup. Neste sentido, estamos motivados para crescer mais e a um ritmo maior, seja na cobertura geográfica, seja em número dos investigadores e, ainda, em produção técnica e científica. De imediato procuraremos estender a nossa rede e iniciar a cobertura da Diáspora. 